\title{
Differentiation of adipose-derived stem cells into Schwann cell phenotype induces expression of P2X receptors that control cell death
}

\author{
A Faroni $^{\star, 1,2}$, SW Rothwell ${ }^{2}$, AA Grolla ${ }^{2}$, G Terenghi $^{1}$, V Magnaghi $^{3}$ and A Verkhratsky ${ }^{2}$
}

Schwann cells (SCs) are fundamental for development, myelination and regeneration in the peripheral nervous system. Slow growth rate and difficulties in harvesting limit SC applications in regenerative medicine. Several molecules, including receptors for neurosteroids and neurotransmitters, have been suggested to be implicated in regulating physiology and regenerative potential of SCs. Adipose-derived stem cells (ASCs) can be differentiated into SC-like phenotype (dASC) sharing morphological and functional properties with SC, thus representing a valid SC alternative. We have previously shown that dASC express $\gamma$-aminobutyric-acid receptors, which modulate their proliferation and neurotrophic potential, although little is known about the role of other neurotransmitters in ASC. In this study, we investigated the expression of purinergic receptors in dASC. Using reverse transriptase (RT)-PCR, western blot analyses and immunocytochemistry, we have demonstrated that ASCs express $\mathrm{P} 2 \mathrm{X}_{3}, \mathrm{P} 2 \mathrm{X}_{4}$ and $\mathrm{P} 2 \mathrm{X}_{7}$ purinoceptors. Differentiation of ASCs towards glial phenotype was accompanied by upregulation of $\mathrm{P} 2 \mathrm{X}_{4}$ and $\mathrm{P} 2 \mathrm{X}_{7}$ receptors. Using $\mathrm{Ca}^{2+}$-imaging techniques, we have shown that stimulation of purinoceptors with adenosine $5^{\prime}$-triphosphate (ATP) triggers intracellular $\mathrm{Ca}^{2+}$ signals, indicating functional activity of these receptors. Whole-cell voltage clamp recordings showed that ATP and BzATP induced ion currents that can be fully inhibited with specific P2X $_{7}$ antagonists. Finally, using cytotoxicity assays we have shown that the increase of intracellular $\mathrm{Ca}^{2}{ }^{2}$ leads to dASC death, an effect that can be prevented using a specific $\mathrm{P}_{2} \mathrm{X}_{7}$ antagonist. Altogether, these results show, for the first time, the presence of functional $\mathrm{P} 2 \mathrm{X}_{7}$ receptors in dASC and their link with critical physiological processes such as cell death and survival. The presence of these novel pharmacological targets in dASC might open new opportunities for the management of cell survival and neurotrophic potential in tissue engineering approaches using dASC for nerve repair.

Cell Death and Disease (2013) 4, e743; doi:10.1038/cddis.2013.268; published online 25 July 2013

Subject Category: Neuroscience

There is a need for alternative strategies to the treatment of peripheral nerve injuries. ${ }^{1}$ Traumatic lesions of peripheral nerves are common; they affect the quality of patients' life and result in substantial health-care expenditure.,3 Although surgical techniques have seen great advances in recent years, the outcomes of peripheral nerve regeneration remain poor. ${ }^{4}$ In order to improve functional recovery after regeneration, efforts are applied to the development of bioengineered nerve grafts consisting of nerve guidance tubes, or conduits, which could be enriched with extracellular matrix molecules, growth factors or transplantable cells. ${ }^{5}$

Nerve injury involves the response of Schwann cells (SCs), the glial cells of the peripheral nervous system. ${ }^{6}$ Damage to the nerve induces remodelling of SC phenotype that eventually aids the outgrowing axon to reach the target of reinnervation. ${ }^{7,8}$ For these reasons, SCs were the first cells to be transplanted in bioengineered nerve grafts, thereby improving nerve regeneration; ${ }^{9-11}$ however, the slow expansion rate and difficulties in harvesting limit deployment of SCs as transplantable cells. ${ }^{12}$ Adipose-derived stem cells (ASCs) are a clinically viable alternative to SC. ${ }^{13-18}$ SC-like differentiated ASCs (dASC) express glial markers and growth factors, ${ }^{14,18}$ produce myelin, ${ }^{15,19,20}$ induce neurites outgrowth in vitro ${ }^{14,20,21}$ and promote nerve regeneration in vivo. ${ }^{22-25}$

Cell transplantation technologies depend upon the survival of transplanted cells that defines the final outcome. In the case of cell transplantation for nerve repair, the survival rates of transplanted cells are not always reported; however, most studies estimated these between 0.5 and $38 \%$, depending on cell type and evaluation time point(s). ${ }^{26-28}$ Despite relatively low survival rate, cell transplantation improves nerve regeneration, probably because of an initial boost generated by the transplanted cells, which arguably may recruit endogenous SC. ${ }^{26,27}$ Nonetheless, improving the survival

\footnotetext{
${ }^{1}$ Faculty of Medical and Human Sciences, The University of Manchester, Manchester, UK; ${ }^{2}$ Faculty of Life Sciences, The University of Manchester, Manchester, UK and ${ }^{3}$ Department of Pharmacological and Biomolecular Sciences, Universitá degli Studi di Milano, Milan, Italy.

*Corresponding author: A Faroni, Blond McIndoe Laboratories, Institute of Inflammation and Repair, The University of Manchester.3.108 Stopford Building, Oxford Road, Manchester M13 9PT, UK. Tel: + 44 (0)16 1275 5193; Fax: + 44 (0)16 1275 1814; Email: alessandro.faroni@manchester.ac.uk

Keywords: adipose-derived stem cells; ATP; purinergic receptors; peripheral nerve regeneration; Schwann-like cells; cell death

Abbreviations: ASC, adipose-derived stem cells; uASC, undifferentiated ASC; SC, Schwann cells; aSC, adult SC; nSC, neonatal SC; dASC, SC-like differentiated ASC; SCGM, stem cell growth media; FBS, fetal bovine serum; fsk, forskolin; GABA, $\gamma$-aminobutyric acid; GFAP, glial fibrillary acidic protein; GGF-2, glial growth factor-2; HRP, horseradish peroxidase; KRB, Krebs-Ringer-modified buffer; LDH, lactate dehydrogenase; MTS, [3-(4,5-dimethylthiazol-2-yl)-5-(3-carboxymethoxyphenyl)-2(4-sulfophenyl)-2H-tetrazolium]; P-S, penicillin-streptomycin solution; PBS, phosphate-buffered solution; TBS, Tris-buffered saline; RT-PCR, reverse transcriptase-PCR; BzATP, $2^{\prime}\left(3^{\prime}\right)$-O-(4-Benzoylbenzoyl)adenosine-5'-triphosphate tri(triethylammonium) salt

Received 07.4.13; revised 24.5.13; accepted 19.6.13; Edited by D Bano
} 
rate and the neurotrophic potential of dASC could be the key requirement for their clinical employability in nerve repair.

Several molecules such as neurosteroids, growth hormones and neurotransmitters have been suggested as potential pharmacological modulators of SC physiology. ${ }^{29}$ In particular, neurotransmitters such as $\gamma$-aminobutyric acid (GABA) and adenosine $5^{\prime}$-triphosphate (ATP) have been shown to affect $S C$ functional responses and differentiation. ${ }^{30-34}$ Recently, we have shown that dASC express functional GABA and $G_{A B A}$ receptors that modulate $S C$ proliferation and release of neurotrophic factors. ${ }^{35-37}$ The expression of other neurotransmitter receptors in dASC has not been investigated, although purinergic receptors influence the adipogenic and osteogenic differentiation of human ASC. ${ }^{38}$

Purinergic signalling is one of the most pervasive mechanisms of intercellular communication, known to control physiological functions of glial cells, such as proliferation, motility, survival, differentiation and myelination. ${ }^{39,40}$ Purinoceptors are classified as metabotropic P1 adenosine receptors, metabotropic P2Y purinoceptors and ionotropic P2X purinoceptors. ${ }^{40} \mathrm{P} 2 \mathrm{X}$ receptors are ligand-gated cationic channels, which assemble in trimeric form (either homo- or heteromultimers) from seven different subunits (designated as $\left.\mathrm{P} 2 \mathrm{X}_{1-7}\right) .{ }^{40,41}$ Stimulation of purinergic receptors has been associated with multiple long-term trophic effects, involved in the regulation of cell replication, proliferation, differentiation and cell death. ${ }^{42}$ Tissue damage is often associated with massive increase of ATP on the injury site, which induces neuronal cell death following spinal cord injuries, an effect that is prevented by $\mathrm{P} 2 \mathrm{X}_{7}$-specific antagonists. ${ }^{43}$

The aim of this study was to determine the presence of functional purinoceptors in dASC and to identify the association between activation of purinoceptors and cell death, an effect that could be responsible for the low survival rate of dASC when transplanted in nerve injury models. Purinoceptors could provide a new pharmacological target to improve cell survival in bioengineered nerve grafts for the treatment of peripheral nerve injuries.

\section{Results}

dASCs express mRNAs of multiple P2X receptors. Following a previously established protocol, ${ }^{35,36}$ undifferentiated ASCs (UASC) were successfully differentiated into SC-like cells. Following harvesting, uASC presented a typical fibroblast-like flattened morphology (Figure 1a). After 2 weeks of differentiation in glial conditioning media, cells acquired a spindle-shaped morphology (Figure 1b) similar to genuine nerve-derived neonatal SC (nSC) that were used as controls (Figure 1c). Successful differentiation was also confirmed by expression of glial markers, as previously described. ${ }^{14,35,36}$ Representative glial fibrillary acidic protein (GFAP) immunostainings of UASC, dASC and nSC are shown in red in Figures $1 \mathrm{~d}-\mathrm{f}$, respectively.

The presence of mRNAs for the $\mathrm{P}_{2 \mathrm{X}_{1-7}}$ purinoceptors was assessed by reverse-transcriptase PCR (RT-PCR). Specific primers listed in Table 1 were used to detect amplicons for the different P2X receptors. A specific product of $440 \mathrm{bp}$ corresponding to $\mathrm{P}_{2} \mathrm{X}_{3}$ receptor was detected in both uASC and dASC as well as in the controls nSC and adult SC (aSC) (Figure 2). SC-like differentiation did not seem to affect $P 2 X_{3}$ mRNA levels. A 447-bp product, corresponding to $\mathrm{P}_{2} \mathrm{X}_{4}$ receptor was detected in $U A S C$ and seemed to be increased following glial differentiation. $\mathrm{P}_{2} \mathrm{X}_{4}$ mRNAs were found also in the positive controls $\mathrm{nSC}$ and aSC. Similarly, $\mathrm{P}_{2} \mathrm{X}_{7}$ transcripts (354 bp) were found to be strongly upregulated in dASC with levels comparable to the positive controls (Figure 2).

$\mathrm{P} 2 \mathrm{X}_{1}, \mathrm{P} 2 \mathrm{X}_{2}$ and $\mathrm{P} 2 \mathrm{X}_{5}$ mRNAs were not detected despite increasing the amount of starting mRNA template to $10 \mathrm{ng}$ (data not shown). A reaction with $10 \mathrm{ng}$ of mRNA produced specific amplicons for $\mathrm{P}_{2} \mathrm{X}_{6}$ receptors in aSC and nSC (rather faint signal); however, no signal was detected in uASC and dASC (Figure 2).

$\mathrm{P}_{2} \mathrm{X}_{4}$ and $\mathrm{P} 2 \mathrm{X}_{7}$ receptor proteins are upregulated in dASC. The expression of $\mathrm{P}_{2} \mathrm{X}_{4}$ and $\mathrm{P}_{2} \mathrm{X}_{7}$ receptors was also investigated at a protein level by western blot analysis. Using a specific antibody raised against $\mathrm{P}_{2} \mathrm{X}_{4}$ receptor, a specific band of 50-60 kDa was found in dASC, aSC and nSC, but not in UASC (Figure 3a). Similarly, $\mathrm{P}_{2} \mathrm{X}_{7}$ receptor protein $(70-80 \mathrm{kDa})$ was strongly upregulated in dASC, confirming RT-PCR studies (Figure 3a). aSC and nSC were used as positive controls for western blot studies. Blotting for the housekeeping gene $\beta$-tubulin confirmed equal loading.

Localisation of $\mathrm{P} 2 \mathrm{X}_{4}$ and $\mathrm{P} 2 \mathrm{X}_{7}$ receptor in UASC and dASC was further investigated with immunocytochemistry analyses, and was compared with receptor distribution in $\mathrm{nSC}$. The uASCs presented only faint staining for $\mathrm{P}_{2} \mathrm{X}_{4}$ and $\mathrm{P} 2 \mathrm{X}_{7}$ (green, Figures $3 \mathrm{~b}$ and e, respectively). Immunoreactivities for both $\mathrm{P}_{2} \mathrm{X}_{4}$ (Figure 3c) and $\mathrm{P}_{2} \mathrm{X}_{7}$ (Figure 3f) were increased in the course of glial differentiation. Increased staining was observed in the cells that underwent glial differentiation with a characteristic change of morphology indicative of differentiated state. Previous quantitative analyses from our group have indicated that $81.5 \pm 1.5 \%$ cells undergo morphological change. ${ }^{14}$ Distribution of $\mathrm{P} 2 \mathrm{X}_{4}$ and $\mathrm{P} 2 \mathrm{X}_{7}$ was detected throughout the cytoplasm of $\mathrm{dASC}$, with distribution pattern similar to $\mathrm{nSC}$ (Figures $3 \mathrm{~d}$ and $\mathrm{g}$ ).

Stimulation of purinoceptors in dASC evokes intracellular $\mathrm{Ca}^{2+}$ signals. Using a $\mathrm{Ca}^{2+}$-sensitive dye (Fura-2), concentration dependence of ATP-induced cytoplasmic $\mathrm{Ca}^{2+}$ changes in UASC and dASC were recorded with a Flexstation microplate reader. Both uASC (Figure 4a) and dASC (Figure 4b) showed a rapid dose-dependent increase in $\mathrm{Ca}^{2+}$-dependent intracellular fluorescence. The pattern and concentration dependence of responses were, however, different in the two cell types confirming the putative presence of a different complements of purinergic receptors, as suggested by molecular studies. Indeed, whereas UASC response to ATP saturated at $100 \mu \mathrm{M}$, in dASC intracellular $\mathrm{Ca}^{2+}$ signals did not saturate even at $1 \mathrm{mM}$ ATP (Figure 4c). Intracellular $\mathrm{Ca}^{2+}$ increase following ATP stimulation was further confirmed by confocal imaging using a different $\mathrm{Ca}^{2+}$-sensitive dye (Fluo-4). Levels of fluorescence (green) were rapidly and strongly increased in the majority of the dASC treated with $1 \mathrm{mM}$ of ATP (Figure $4 \mathrm{~g}$ ).

To investigate the contribution of the metabotropic P2Y receptors, experiments were repeated in the absence of 

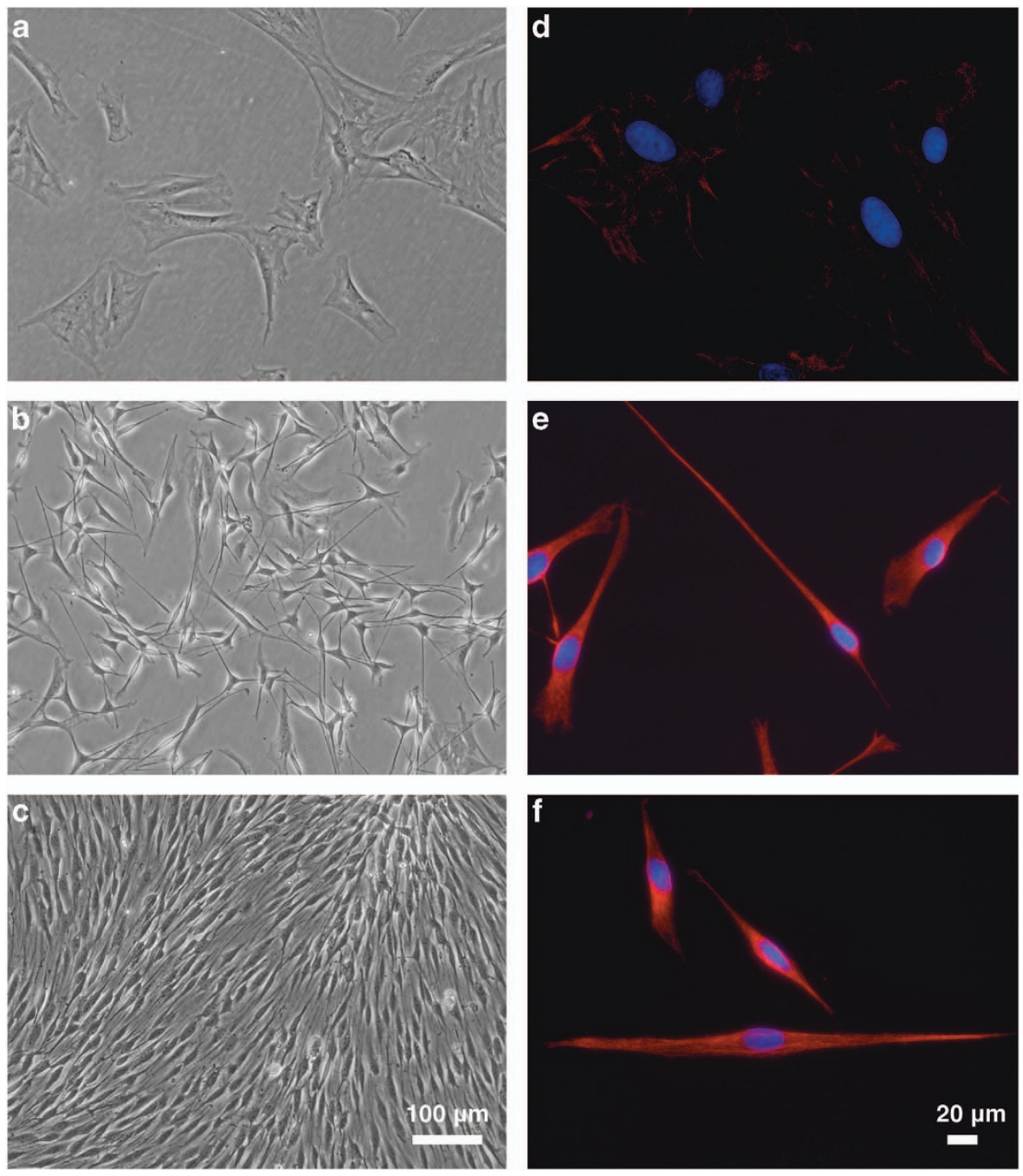

Figure 1 Differentiation of ASC into glial phenotype. (a) UASCs show fibroblast-like morphology that changed following exposure to glial induction media. (b) dASC show spindle-shaped morphology typical of SC, these later displayed in (c). (d, e and f) Staining for the glial marker GFAP confirmed successful differentiation of dASC (red in e), with a similar pattern of localisation as nSC (f) used as control uASCs (d) showed only faint GFAP staining. Nuclei are stained with DAPI (4',6- diamidino-2-phenylindole)

Table 1 Specific primers used for RT-PCR studies

\begin{tabular}{|c|c|c|c|c|}
\hline Gene & AN GenBank & Primer sequence $\left(5^{\prime}-3^{\prime}\right)$ & AT $\left({ }^{\circ}\right)$ & PL (bp) \\
\hline$P 2 X_{1}$ & X80447 & $\begin{array}{l}\text { F: GAAGTGTGATCTGGACTGGCACGT } \\
\text { R: GCGTCAAGTCCGGATCTCGACTAA }\end{array}$ & 58 & 452 \\
\hline$P 2 X_{2}$ & U14414 & $\begin{array}{l}\text { F: GAATCAGAGTGCAACCCCAA } \\
\text { R: TCACAGGCCATCTACTTGAG }\end{array}$ & 61 & 357 \\
\hline$P 2 X_{3}$ & X90651 & $\begin{array}{l}\text { F: TGGCGTTCTGGGTATTAAGATCGG } \\
\text { R: CAGTGGCCTGGTCACTGGCGA }\end{array}$ & 58 & 440 \\
\hline$P 2 X_{4}$ & X87763 & $\begin{array}{l}\text { F: GAGGCATCATGGGTATCCAGATCAAG } \\
\text { R: GAGCGGGGTGGAAATGTAACTTTAG }\end{array}$ & 58 & 447 \\
\hline$P 2 X_{5}$ & X92069 & $\begin{array}{l}\text { F: GCCGAAAGCTTCACCATTTCCATAA } \\
\text { R: CCTACGGCATCCGCTTTGATGTGATAG }\end{array}$ & 58 & 418 \\
\hline$P 2 X_{6}$ & X92070 & $\begin{array}{l}\text { F: AAAGACTGGTCAGTGTGTGGCGTTC } \\
\text { R: TGCCTGCCCAGTGACAAGAATGTCAA }\end{array}$ & 64 & 520 \\
\hline$P 2 X_{7}$ & X95882 & $\begin{array}{l}\text { F: GTGCCATTCTGACCAGGGTTGTATAAA } \\
\text { R: GCCACCTCTGTAAAGTTCTCTCCGATT }\end{array}$ & 58 & 354 \\
\hline$\beta$-actin & NM031144 & $\begin{array}{l}\text { F: CACCACAGCTGAGAGGGAAATCGTGCGTGA } \\
\text { R: ATTTGCGGTGCACGATGGAGGGGCCGGACT }\end{array}$ & 60 & 510 \\
\hline
\end{tabular}

Abbreviations: AN GenBank, accession number; AT, annealing temperature; F, forward; PL, product length; R, reverse. Sequences from Shibuya et al ${ }^{61}$ 

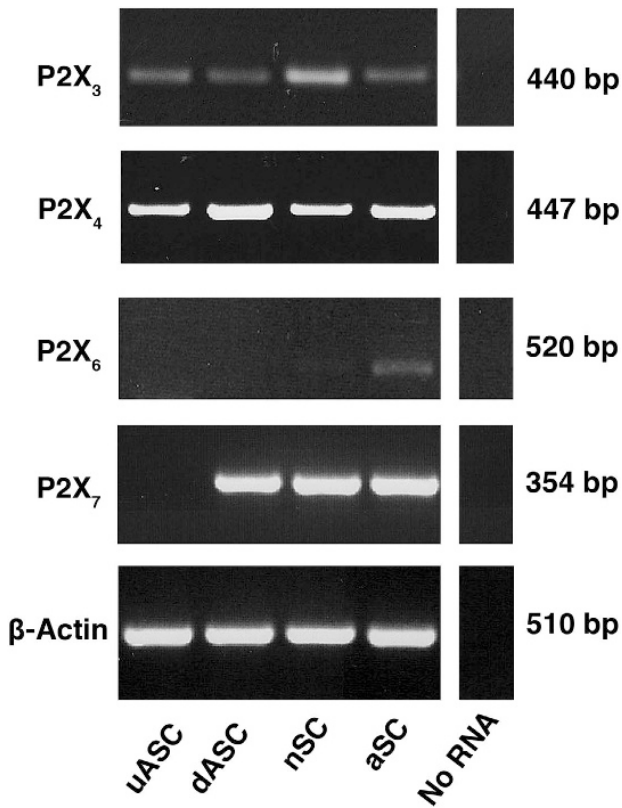

Figure 2 Qualitative RT-PCR for P2X receptors. ASCs were found to express mRNAs for $P 2 X_{3}$ and $P 2 X_{4}$ receptors. $P 2 X_{4}$ and $P 2 X_{7}$ receptors were upregulated in $\mathrm{dASC}$. However, $P 2 \mathrm{X}_{6}$ transcripts were not detected in ASC despite increasing the amount of the starting RNA template. aSC, nSC total RNA were used as positive controls. $\beta$-actin was used as a loading control and a reaction omitting the template was used as a negative control

extracellular $\mathrm{Ca}^{2+}$. Both uASC (Figure 4d) and dASC (Figure $4 \mathrm{e}$ ) showed ATP-induced $\mathrm{Ca}^{2+}$ response despite the absence of $\mathrm{Ca}^{2+}$ in an extracellular reservoir, suggesting the release of $\mathrm{Ca}^{2+}$ from intracellular stores linked, in all probability, to activation of $\mathrm{P} 2 \mathrm{Y}$ receptors. Concentration dependence of $\mathrm{Ca}^{2+}$ responses was different between uASC and $d A S C$, suggesting that expression pattern of P2Y receptors may also be remodelled following glial differentiation. Indeed, whereas in UASC the ATP-dependent $\mathrm{Ca}^{2+}$ fluorescence was saturated at $30 \mu \mathrm{M}$ ATP, in dASC saturation was reached only at $300 \mu \mathrm{M}$ ATP (Figure 4f).

To identify the P2X-mediated component of intracellular $\mathrm{Ca}^{2+}$ increase, specific $\mathrm{P} 2 \mathrm{X}_{7}$ inhibitors were used to block the receptors before ATP stimulation. $\mathrm{Ca}^{2+}$ signals recorded from dASC in response to $1 \mathrm{mM}$ ATP were significantly inhibited by the treatment with a potent and specific antagonist for $\mathrm{P}_{2} \mathrm{X}_{7}$ receptor (AZ 10606120 dihydrochloride, $300 \mathrm{nM})$, suggesting the presence of functional $\mathrm{P}_{2} \mathrm{X}_{7}$ receptors. The area under the curve (AUC) of the $\mathrm{Ca}^{2+}$ traces recorded from the samples pretreated with the inhibitor was indeed significantly reduced $(10.09 \pm 0.45)$ compared with the samples treated only with ATP (17.69 \pm 0.45 , AUC arbitrary units, $n=4,{ }^{\star \star} P<0.01$, Figure $\left.4 \mathrm{i}\right)$. Another potent, selective and competitive $\mathrm{P}_{2} \mathrm{X}_{7}$ receptor antagonist (A740003, $60 \mu \mathrm{M})$ produced a similar effect $(9.76 \pm 0.32$ ATP versus $7.22 \pm 0.15$ ATP plus inhibitor, $n=4$, ${ }^{* * *} P<0.001$, data not shown). Conversely, pretreatment of UASC with the AZ 10606120 compound did not affect $\mathrm{Ca}^{2+}$ signals confirming that functional $\mathrm{P}_{2} \mathrm{X}_{7}$ receptors are not present in uASC (Figure $4 \mathrm{~h}$ ).
ATP and BzATP trigger P2X $\mathrm{X}_{\mathbf{7}}$-mediated ion currents. We further characterised functional expression of $P 2 X$ receptors in dASCs utilising whole-cell voltage clamp. Either ATP $(3 \mu \mathrm{M}-3 \mathrm{mM})$ or BzATP $\left(2^{\prime}\left(3^{\prime}\right)\right.$-O-(4-Benzoylbenzoyl)adenosine-5'-triphosphate tri(triethylammonium) salt; $3-300 \mu \mathrm{M})$ were applied for $30 \mathrm{~s}$ at 60 -s intervals. Inward currents were observed in dASCs only when ATP was applied at a concentration of $1 \mathrm{mM}$ or higher (Figures $5 \mathrm{a}$ and b). BzATP was more potent than ATP, evoking currents when applied at concentrations starting at $30 \mu \mathrm{M}$ (Figures $5 \mathrm{a}$ and b). ATP-evoked currents were non-desensitizing in the presence of ATP, suggesting operation of $\mathrm{P}_{2} \mathrm{X}_{7}$ receptors. This was further corroborated by testing the effect of the specific $\mathrm{P}_{2} \mathrm{X}_{7}$ inhibitor, $\mathrm{AZ}$ 10606120, on ATP-evoked currents in dASC. The AZ 10606120 compound $(300 \mathrm{nM})$ inhibited ATP-evoked currents by $84 \pm 3 \%(n=7)$, indicating significant contribution of $\mathrm{P}_{2} \mathrm{X}_{7}$ receptors (Figures $5 \mathrm{c}$ and $\mathrm{d}$ ). We were not able to measure currents from uASC owing to the flat morphological nature that makes whole-cell patch clamping technically challenging.

$\mathrm{P} \mathrm{X}_{7}$ receptors mediate $\mathrm{dASC}$ cell death and survival. One of the fundamental effects mediated through activation of $\mathrm{P}_{2} \mathrm{X}_{7}$ receptor is to induce cell death. ${ }^{44,45}$ In order to determine the ATP concentration that, during sustained stimulation, could initiate cell death, we performed a lactate dehydrogenase (LDH) cytotoxicity assay on cultures treated with 0-10 mM ATP. Although $1 \mathrm{mM} \mathrm{ATP} \mathrm{did} \mathrm{not} \mathrm{induce} \mathrm{cell}$ death, a significant increase in cytotoxicity was observed in cultures treated with $5 \mathrm{mM}\left({ }^{\star \star} P<0.01\right)$ and $10 \mathrm{mM}$ $\left({ }^{* \star *} P<0.0001\right)$ of ATP (Figure $6 \mathrm{~b}$ ). For this reason, $5 \mathrm{mM}$ ATP was chosen for the rest of cell death studies. In order to assess whether the observed cell death was dependent from $\mathrm{P}_{2} \mathrm{X}_{7}$ receptors activation, cultures were treated with $5 \mathrm{mM}$ ATP together with specific $P 2 X_{7}$ antagonists. Cells treated with $5 \mathrm{mM}$ ATP showed a significantly increased level of cell death $(19.03 \pm 0.67 \%)$ compared with untreated cultures $\left(11.59 \pm 0.59 \%,{ }^{* \star *} P<0.0001\right.$, Figure 6c). Pretreatment with the AZ 10606120 compound $(300 \mathrm{nM})$ prevented this ATP-induced cell death and significantly reduced the level of cytotoxicity $\left(11.56 \pm 0.39 \%,{ }^{* * * *} P<0.0001\right)$. These effects were also observed by examination under a bright field microscope (Figure 6a). In samples treated with ATP, dASC assumed a rounded morphology typical of dying cells and were eventually detached, an effect prevented by preincubation of cultures with $\mathrm{P}_{2} \mathrm{X}_{7}$ antagonist (Figure 6a). In order to assess cell viability following ATP treatments, a [3-(4,5-dimethylthiazol-2-yl)-5-(3-carboxymethoxyphenyl)2-(4-sulfophenyl)-2H-tetrazolium], (MTS)-based cell survival assay was performed (Figure 6d). Treatment with $5 \mathrm{mM}$ ATP significantly reduced dASC viability compared with untreated controls $\left(90.21 \pm 1.29 \%\right.$ versus $100.0 \pm 1.64 \%$, $\left.{ }^{\star \star \star} P<0.001\right)$, confirming LDH results. Pretreatment with AZ 10606120 dihydrochloride $(300 \mathrm{nM})$ prevented the ATP-mediated decrease of cell viability and restored the survival rate of treated dASC at the levels of the non-treated cells $\left(101.4 \pm 1.47 \%,{ }^{* *} P<0.001\right)$. Furthermore, a third cell viability assay, based on a membrane-impermeant viability 
a
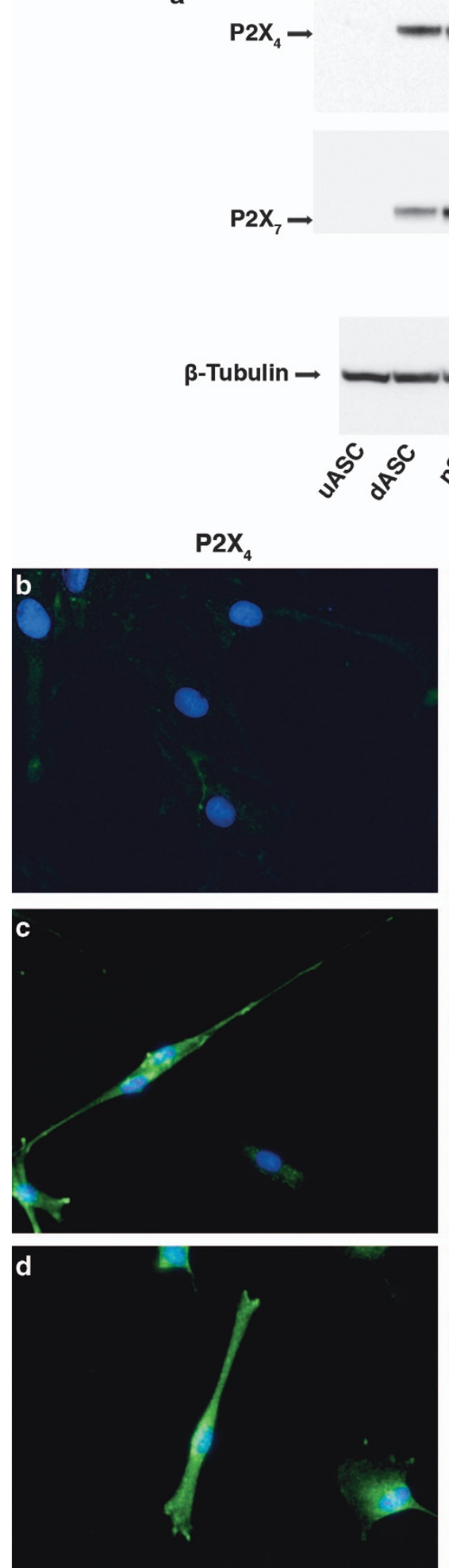

- $60 \mathrm{kDa}$

- $50 \mathrm{kDa}$

$-40 \mathrm{kDa}$

$-160 \mathrm{kDa}$

- $110 \mathrm{kDa}$

- $80 \mathrm{kDa}$

- $60 \mathrm{kDa}$

- $50 \mathrm{kDa}$

- $60 \mathrm{kDa}$

- $50 \mathrm{kDa}$

- $40 \mathrm{kDa}$

$\mathrm{P} \mathrm{X}_{7}$
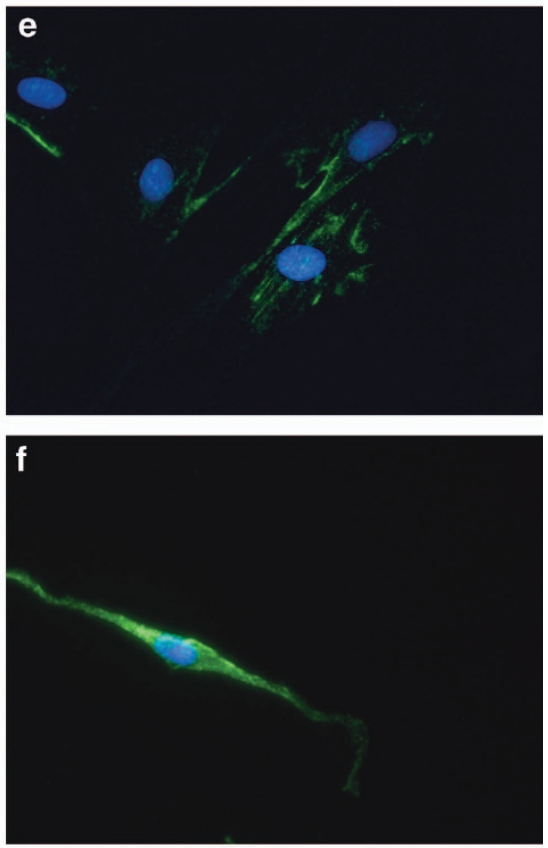

g

$20 \mu \mathrm{m}$

Figure $3 P 2 X_{4}$ and $P 2 X_{7}$ receptor proteins are upregulated in $d A S C$. (a) $P 2 X_{4}$ and $P 2 X_{7}$ proteins were not detected in uASC by western blot analysis. Both $P 2 X_{4}$ and $P 2 X_{7}$ receptor proteins were upregulated in dASC to levels comparable to aSC and nSC. The housekeeping gene $\beta$-tubulin was used to verify equal loading. (b-g) Staining for $P 2 X_{4}$ receptors is faint in UASC (b) and strongly increased in AASC (c), with a pattern similar to nSC (d). Similarly, uASC showed poor positive staining for P2X $\mathrm{X}_{7}$ receptor $(\mathbf{e})$, but staining was increased in dASC (f) becoming comparable to nSC (g). P2X receptors are stained in green and nuclei are stained with DAPI (4',6- diamidino-2-phenylindole). Negative controls with omission of primary antibodies were performed for each cell type and showed no staining (data not shown) 

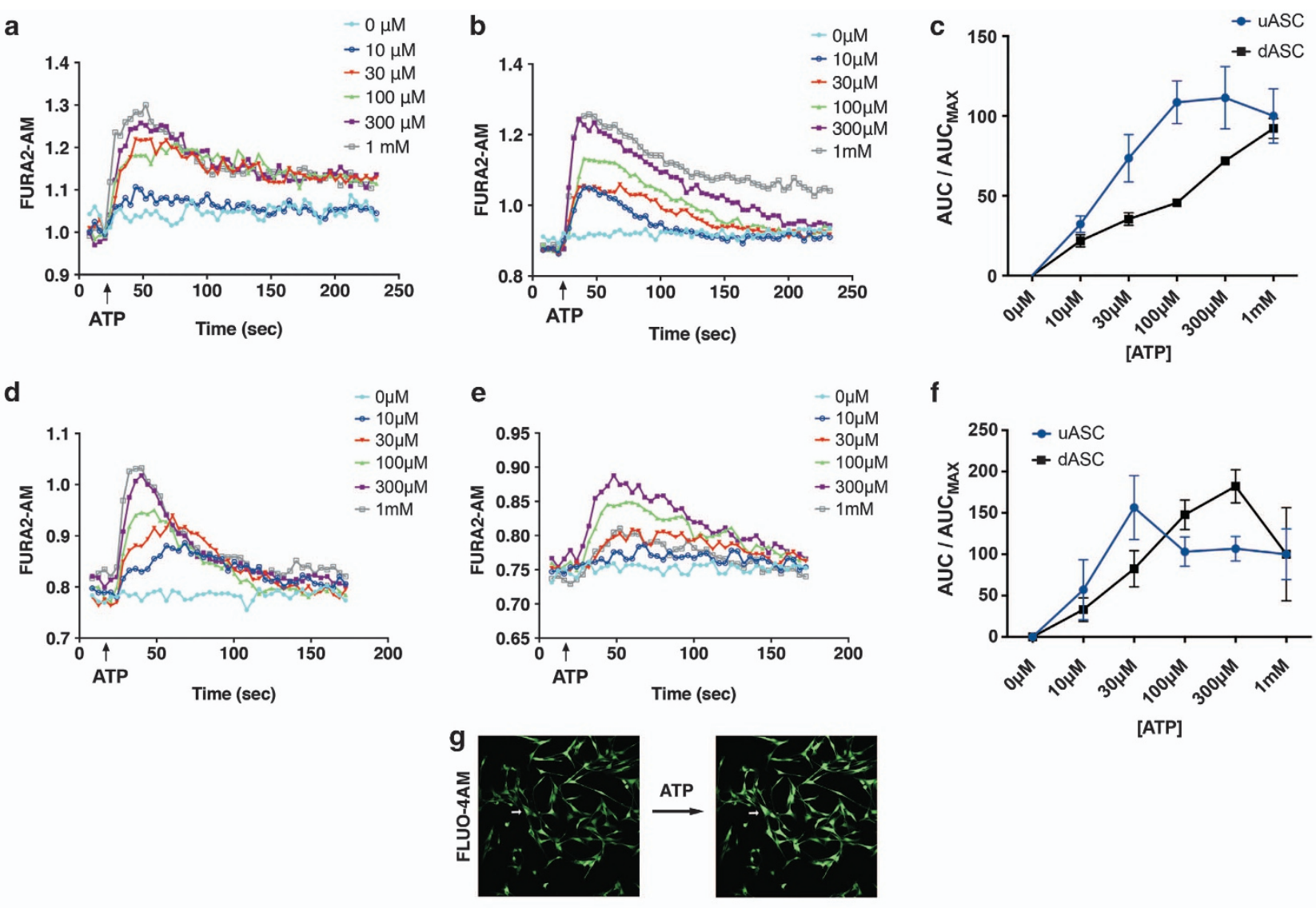

[ATP]
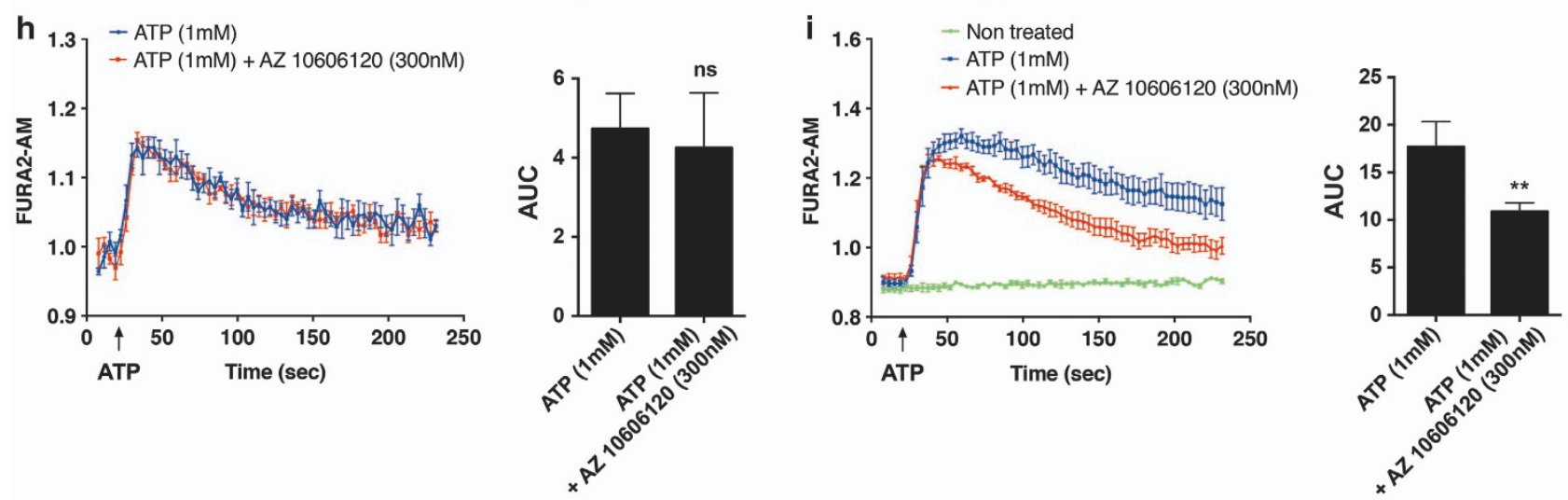

Figure 4 Intracellular $\mathrm{Ca}^{2+}$ signalling induced by stimulation with ATP. (a-c and g) uASC (a) and dASC (b) showed a dose-dependent increase of intracellular $\mathrm{Ca}^{2+}$ concentration following exposure to ATP, as measured by Fura-2 fluorescence $(n=3)$. uASC and dASC showed a different ATP sensitivity (c), as shown from the quantified AUCs normalised for the maximal response. Intracellular $\mathrm{Ca}^{2+}$ increase following ATP treatment ( $1 \mathrm{mM}$ ) was also confirmed by confocal imaging of dASC cultures stained with Fluo-4 (g). (d-f) P2Y contribution to intracellular $\mathrm{Ca}^{2+}$ increase was assessed by performing $\mathrm{Ca}^{2+}$ recordings in $\mathrm{Ca}^{2+}$-free extracellular solutions; $u A S C$ (d) and dASC (e) showed a different pattern of responses, which saturated at different ATP concentrations (f) $n=3$. (h and i) In dASC (i), incubation with A10606120 dihydrochloride $(300 \mathrm{nM})$, a potent and specific $\mathrm{P} 2 \mathrm{X}_{7}$ antagonist, significantly reduced the intracellular $\mathrm{Ca}^{2+}$ increase evoked by ATP treatments $\left(n=4\right.$, $\left.{ }^{* *} P<0.01\right)$. This was not observed in uASC (h). Statistical analysis was performed using unpaired $t$-test. Treatments with drug vehicle did not induce any fluorescence changes

indicator ethidium homodimer-1 (EthD-1), was performed. The number of cell stained with EthD-1 was significantly increased in the samples treated with $5 \mathrm{mM}$ ATP compared with non-treated (NT) controls $(617 \pm 33$ versus $188 \pm 17$, $\left.n=6,{ }^{\star \star \star} P<0.001\right)$. Nonetheless, preincubation with the $\mathrm{AZ}$ 10606120 dihydrochloride compound $(300 \mathrm{nM})$ prevented the ATP-dependent increase of dead cells and reduced the number of dead cells stained with EthD-1 to the level of NT controls of $224 \pm 71, n=6$ (Figure 6e).

\section{Discussion}

In this study, we have shown for the first time that specific purinoceptors are upregulated in ASCs differentiated into a SC-like phenotype and that they control cell death and survival.

In recent years, dASCs have been suggested as a promising source of transplantable cells for peripheral nerve repair. ${ }^{1}$ Several in vitro and in vivo studies demonstrated that dASCs share morphological, molecular and functional 
a
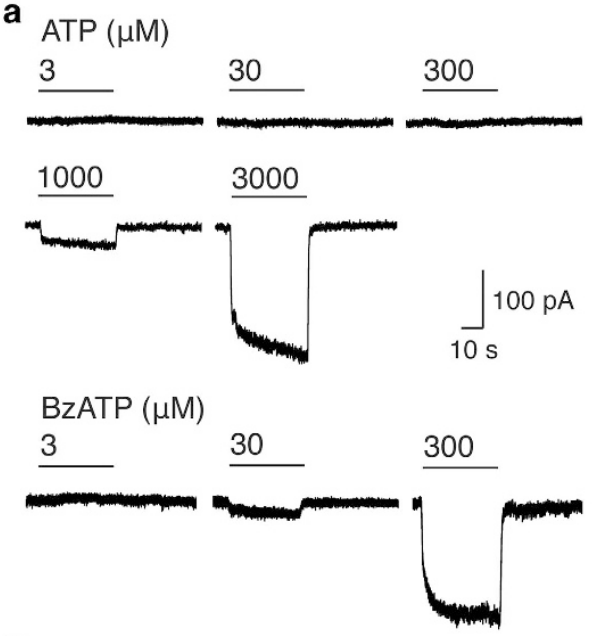

C

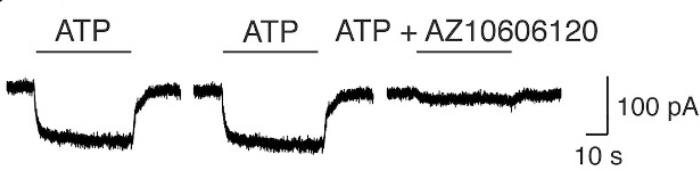

b

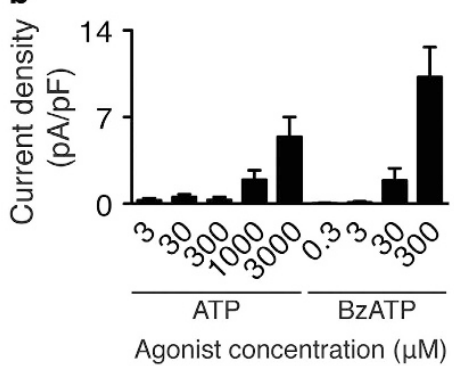

d

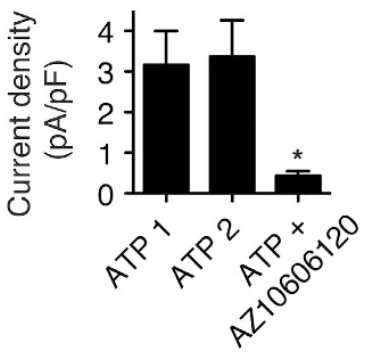

Figure $5 \mathrm{P} 2 \mathrm{X}_{7}$ ion currents in dASCs. (a) Representative recordings of ion currents measured from dASC in response to application of increasing concentrations of ATP (upper traces) and BzATP (lower traces); agonists were applied for $30 \mathrm{~s}$ with 60-s intervals. (b) The concentration dependence of peak amplitude of ion currents recorded as in (a); $n=6-10$ for ATP and 5-10 for BzATP. (c and d) Inhibition of ATP-induced ion currents by P2X 7 antagonist AZ 10606120; ATP was applied at 3 mM for 30 s; AZ 10606120 at $300 \mathrm{nM}$ was added to the bath 1-2 min before ATP challenge and remained in the presence of ATP; the average values for peak amplitudes in control and in the presence of the antagonist are shown in (d). Statistical analysis was performed using one-way analysis of variance (ANOVA) followed by Tukey's multiple comparison test, $n=7$, ${ }^{*} P<0.05$

similarities with native SC, with the additional advantage of being easily cultured and rapidly expandable. ${ }^{14,19,22,23,46}$ When transplanted in rat in vivo models of peripheral nerve injury, they were able to promote regeneration and remyelinate injured axons. ${ }^{18,20,22,23}$ We have previously shown that $\mathrm{GABA}_{\mathrm{B}}$ receptors expressed in dASCs represent a potential pharmacological target to improve their neurotrophic potential. $^{35-37}$ Pharmacological targeting of dASC neurotransmitters receptors could constitute a clinically viable option for the development of cell-based therapies for peripheral nerve injuries.

Embryonic stem cells, hematopoietic stem cells, bone marrow stem cells and neuronal progenitors have been shown to respond to ATP stimulation, but the specific pattern of receptors responsible for such responses remains virtually unknown. ${ }^{38}$ In this paper, we have demonstrated that ASCs express specific subtypes of $\mathrm{P} 2 \mathrm{X}$ ionotropic purinoceptors. The expression of $\mathrm{P} 2 \mathrm{X}_{3}, \mathrm{P}_{2} \mathrm{X}_{4}$ and $\mathrm{P} 2 \mathrm{X}_{7}$ receptors, but not $\mathrm{P} 2 \mathrm{X}_{1}$ and $\mathrm{P} 2 \mathrm{X}_{2}$ mRNAs was detected, which is in accordance with a recent study in human ASCs. ${ }^{38}$ In contrast to previous data, however, we were not able to detect $\mathrm{P}_{2} \mathrm{X}_{5}$ and $\mathrm{P} 2 \mathrm{X}_{6}$ receptors mRNAs. This difference could reflect different cell culture conditions or interspecies differences. In uASC, $\mathrm{P}_{2} \mathrm{X}_{4}$-specific mRNA transcripts were detected, whereas protein was not. This discrepancy could be attributed to a different turnover of $\mathrm{P}_{2} \mathrm{X}_{4} \mathrm{mRNA}$ and proteins, as well as to the diverse detection limits of the two techniques.

Differentiation along a glial phenotype was accompanied by upregulation of $\mathrm{P}_{2} \mathrm{X}_{4}$ and $\mathrm{P}_{2} \mathrm{X}_{7}$ receptors that complements other reports demonstrating a rearrangement in expression when differentiated towards an adipogenic or osteogenic phenotype. $^{39}$ It is known that myelinating potential and proliferation is regulated through ATP acting on P2 purinoceptors on SCs during development. ${ }^{47}$ The role of purinoceptors in long-term trophic signalling pathways affecting cell proliferation, differentiation, motility and death is well known. ${ }^{42}$ In particular, $\mathrm{P}_{2} \mathrm{X}_{7}$ receptors have been shown to mediate cell death in a wide variety of cell types, most notably oligodendrocytes. ${ }^{40,42}$ Indeed, oligodendrocytes express $\mathrm{P}_{2} \mathrm{X}_{7}$ receptors, which can induce cell death, causing lesions that resemble demyelinating conditions such as multiple sclerosis. ${ }^{48}$ This suggests the possibility of targeting glial $\mathrm{P}_{2} \mathrm{X}_{7}$ receptors for the management of demyelinating conditions of the central nervous system. Opening of $\mathrm{P}_{2} \mathrm{X}_{7}$ receptors requires much higher (in $\mathrm{mM}$ range) ATP concentrations than other $\mathrm{P} 2 \mathrm{X}$ receptor subtypes (in $\mu \mathrm{M}$ range). Transient ATP stimulation opens the $\mathrm{P}_{2} \mathrm{X}_{7}$ channel to small cations (that is, $\mathrm{Na}^{+}, \mathrm{K}^{+}$and $\mathrm{Ca}^{2+}$ ), whereas a continued exposure to ATP triggers the formation of larger transmembrane pores, determining excessive $\mathrm{Ca}^{2+}$ influx with consequent changes in intracellular ions and metabolites concentrations, leading to cell death. ${ }^{49,50}$

We have found that stimulation of both uASCs and dASCs with ATP triggers transient increase in the intracellular $\mathrm{Ca}^{2+}$ concentration. Concentration dependence of these $\mathrm{Ca}^{2+}$ signals differed between undifferentiated and differentiated cells. UASCs $\mathrm{Ca}^{2+}$ responses saturated at $\sim 100 \mu \mathrm{M}$ ATP, whereas dASCs $\mathrm{Ca}^{2+}$ responses continued to rise at concentrations of ATP of up to $1 \mathrm{mM}$. In both types of cells, $\mathrm{Ca}^{2+}$ responses were maintained in the absence of extracellular $\mathrm{Ca}^{2+}$, indicating activation of metabotropic P2Y receptors; however, only in dASC we detected the component of $\mathrm{Ca}^{2+}$ response activated by high ATP concentrations that was inhibited by specific antagonists of $\mathrm{P}_{2} \mathrm{X}_{7}$ receptors. 

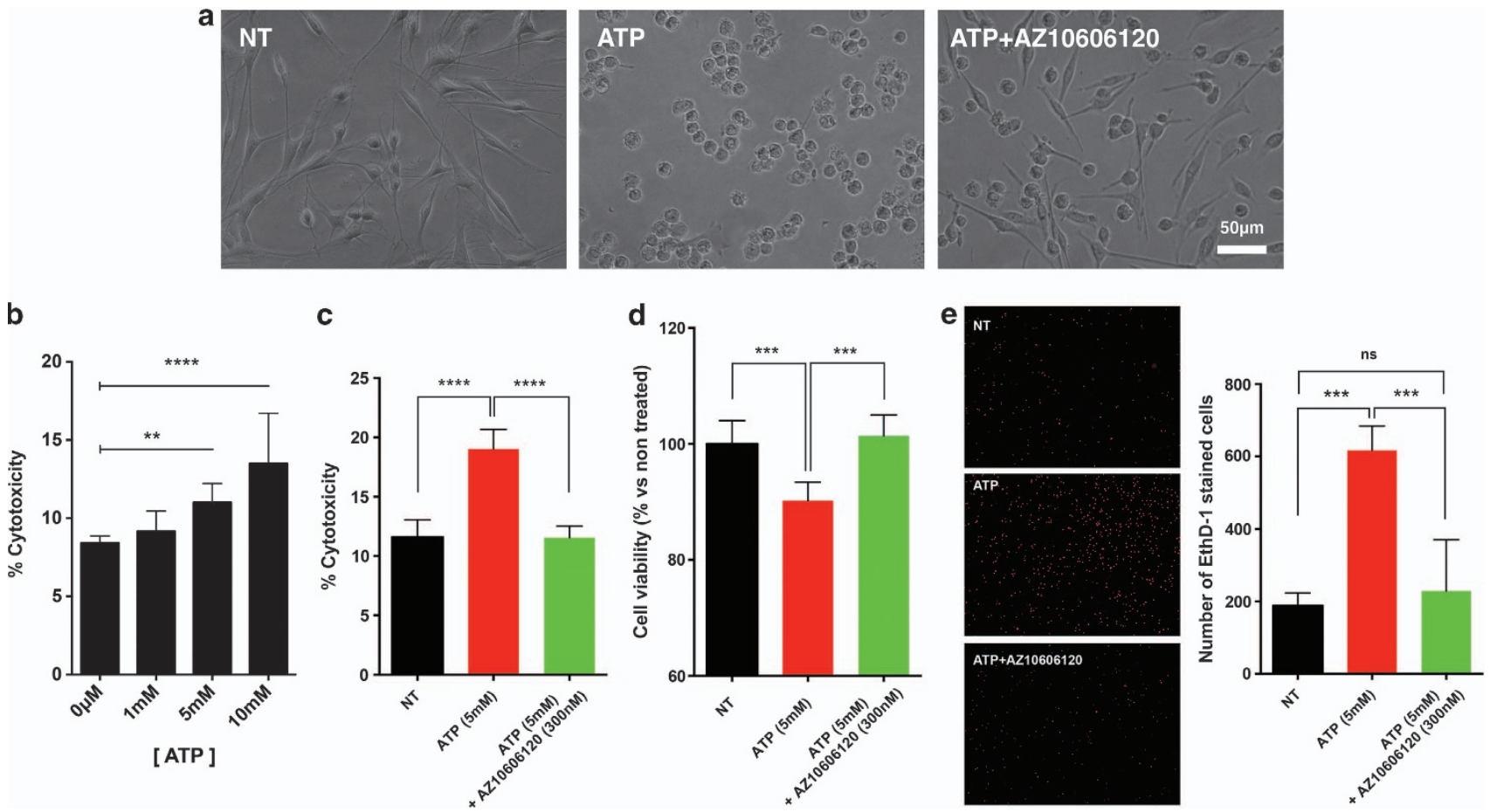

Figure $6 \mathrm{P} 2 \mathrm{X}_{7}$ activation mediates dASC cell death. (a) After $1 \mathrm{~h}$ incubation with $5 \mathrm{mM}$ of ATP, cells acquired a rounded morphology typical of dying cells. Cell death was prevented by preincubation with the specific P2X $\mathrm{X}_{7}$ antagonist AZ 10606120 dihydrochloride $(300 \mathrm{nM})$, as shown by bright field images. NT, non-treated controls. (b) LDH assay was used to measure cytotoxicity following ATP $(1-10 \mathrm{mM})$ treatments, and a significant increase of cell death was observed only at 5 and $10 \mathrm{mM} \mathrm{ATP.} \mathrm{(c)} \mathrm{AZ} 10606120$ dihydrochloride significantly reduced the ATP-induced cytotoxicity to levels comparable to the controls. Data were normalised to the LDH levels of Triton-X lysates and expressed as percentage of cytotoxicity \pm S.E.M. (d) An MTS assay was performed to measure the cell viability ATP treatment significantly reduced cell viability compared with the NT controls. Pretreatment with AZ 10606120 dihydrochloride prevented the ATP-dependent decrease in cell survival restoring cell viability to levels comparable to NT samples. (e) P2X-dependent ATP-induced cell death was further confirmed with EthD-1 staining. Following ATP treatments, the number of death cell stained by EthD-1 was significantly increased. This was prevented by incubation with the AZ 10606120 dihydrochloride compound. For all assays, statistical analysis was performed using one-way analysis of variance (ANOVA) followed by Tukey's multiple comparison test, $n=6,{ }^{* *} P<0.01,{ }^{* *} P<0.001$ and ${ }^{* * * *} P<0.0001$ )

In voltage-clamped dASCs, the non-desensitising current was evoked by ATP at concentrations exceeding $1 \mathrm{mM}$; a similar non-desensitising current was induced by BzATP applied at concentrations above $30 \mu \mathrm{M}$. This ATP-induced ion current was almost completely blocked by specific P2X antagonist AZ 10606120. Low-sensitivity to ATP, absence of desensitisation, agonism by BzATP and antagonism by AZ 10606120 compound collectively substantiate functional expression of $\mathrm{P}_{2} \mathrm{X}_{7}$ receptors in dASCs. These $\mathrm{P}_{2} \mathrm{X}_{7}$ receptors represent the sole component of ionotropic response to ATP, because no currents were detected at ATP applied in concentrations below $1 \mathrm{mM}$. It is noteworthy that P2Y-mediated $\mathrm{Ca}^{2+}$ responses (measured in the absence of extracellular $\mathrm{Ca}^{2+}$ ) also differed between uASC and $\mathrm{dASC}$, indicating possible remodelling of P2Y receptors complement related to cells differentiation, although this requires further investigation.

Functional and expression data indicate that in the process of differentiation to SC phenotype, dASCs acquire functional $\mathrm{P}_{2} \mathrm{X}_{7}$ receptors. These receptors can be linked to dASC survival because an extended exposure to high concentrations of ATP results in cell death linked to their activation. Using cell viability assays, paired with morphological observations, we showed that the pharmacological preconditioning of dASC with a specific $\mathrm{P}_{2} \mathrm{X}_{7}$ antagonist prevented this $\mathrm{P} 2 \mathrm{X}_{7}$-mediated cell death. It is important to consider that the
P2X $\mathrm{X}_{7}$-mediated ATP-induced cell death is not necessarily uniquely linked to the increase of intracellular $\mathrm{Ca}^{2+}$. Indeed, in voltage-clamped dASC, $1 \mathrm{mM}$ ATP induced P2X $\mathrm{X}_{7}$-specific ion currents but this did not translate in dASC cell death, as observed in cell viability studies. Nonetheless, higher concentrations of ATP were shown to fully activate P2X receptors on dASC, and sustained ATP exposure caused cell death. For this reason, the presence of other mechanisms (besides intracellular $\mathrm{Ca}^{2+}$ increase), likely to result from $\mathrm{P}_{2} \mathrm{X}_{7}$ pore formation, should not be excluded and may be worth further investigation.

The presence of functional $\mathrm{P} 2 \mathrm{X}_{7}$ receptors mediating $\mathrm{dASC}$ cell death could represent a novel pharmacological target to improve the survival rate of dASC in stem cell-based approaches for nerve repair. Although cell transplants were able to support axonal regeneration, only $12 \%$ of SC-like bone marrow-derived stem cells were found in peripheral nerve grafts 3 weeks after surgery. ${ }^{51}$ Similarly, only 26000 of SC-like skin-derived precursors out of the 400000 cells originally transplanted were found in remyelinated peripheral nerves 6 weeks after transplantation. ${ }^{52}$ Quantitative data on the survival of dASC following transplantation in nerve injury models are not available; nevertheless, green fluorescent protein-labelled uASCs were not detected 2 weeks after transplantation. ${ }^{26}$ The enhanced axonal regeneration reported in this in vivo model was attributed to an indirect 
effect on endogenous SCs or to an initial regenerative boost signal from transplanted UASC, which were present in high number 3 days after transplantation. ${ }^{26}$

An early death of transplanted SCs was observed in spinal cord injury models with $78 \%$ cell loss within the first week, without a subsequent decrease in cell number. ${ }^{53}$ Delaying the transplantation procedure after injury or injecting SCs in a non-damaged site improved cell survival up to $60 \%{ }^{54}$ This evidence suggests the presence of hostile factors at the injury site, which can facilitate or induce cell death. ${ }^{53,54}$ The loss of cells transplanted into damaged tissue has been associated with hypoxia at the injury site and to nutrients deprivation for the cells, which suffer from tissue culture serum starvation. ${ }^{55,56}$ Nonetheless, the impact of other factors capable of mediating cell death, such as ATP, may not be excluded. It is a generally accepted knowledge that ATP is released in high concentrations at injury sites in the central and peripheral nervous system. ${ }^{49,57}$ In particular, SCs themselves secrete ATP during Wallerian degeneration, which rapidly follows peripheral nerve injury, ${ }^{58}$ and this ATP affects SC dedifferentiation and proliferation. ${ }^{59}$ Moreover, damaged cells at the distal stump of the injury site constitute an additional source of ATP that could be released during membrane damage and cell death. The high concentration of ATP detected at the site of peripheral nerve lesions could be responsible of the low survival rate of transplanted stem cell.

Peripheral nerve injuries are currently treated by surgery aimed at rejoining the ends of a damaged nerve or to fill nerve gaps with an autologous nerve graft. ${ }^{4,60}$ The outcomes of this therapeutic approach are not always satisfying and there is great interest in the development of bioengineered nerve grafts enriched with cells capable of improving nerve regeneration. ${ }^{1}$ Herein, we propose a novel pharmacological approach to improve the survival rate of transplanted cells in bioengineered nerve grafts, exploiting functional $\mathrm{P}_{2} \mathrm{X}_{7}$ receptors on dASC. In this scenario, dASC could be treated with specific $\mathrm{P}_{2} \mathrm{X}_{7}$ antagonist before transplantation to prevent the early cell mortality that occurs at the injury site. ${ }^{53,54}$

\section{Materials and Methods}

Animals and cell cultures. All the experiments requiring animals were performed in accordance with the UK Animals (Scientific Procedures) Act, 1986. Following terminal anaesthesia with $\mathrm{CO}_{2}$ and cervical dislocation, tissues were collected from the animals and processed as required to obtain the different cell cultures.

aSC and nSC cultures. SCs were obtained from the sciatic nerves of neonatal or adult Sprague-Dawley rats using previously established protocols. ${ }^{23,36}$ Cultures were maintained in low-glucose Dulbecco's modified Eagle's medium (Sigma-Aldrich, Dorset, UK) supplemented with $10 \%(\mathrm{v} / \mathrm{v})$ of fetal bovine serum (FBS; Biosera, Uckfield, UK), 1\% (v/v) of penicillin-streptomycin solution (P-S; PAA, Somerset, UK), $10 \mu \mathrm{M}$ forskolin (fsk; Sigma-Aldrich) and $63 \mathrm{ng} / \mathrm{ml}$ of glial growth factor-2 (GGF-2; Acorda Therapeutics Inc., Ardsley, NY, USA). Cells were incubated in $5 \% \mathrm{CO}_{2}$ at $37^{\circ} \mathrm{C}$ and maintained at sub-confluent levels onto poly-Dlysine (Sigma-Aldrich)-coated $75 \mathrm{~cm}^{2}$ flasks, with medium changes every $72 \mathrm{~h}$.

ASCs cultures. ASCs were isolated from subcutaneous, inguinal and visceral fat pads of male adult Sprague-Dawley rats, as described previously. ${ }^{14}$ Briefly, the collected fat pads were joined and mechanically dissociated using sterile scissors and scalpel blades. The fat pads were then further enzymatically dissociated with collagenase Type I (Gibco, Life Technologies, Paisley, UK) and finally filtered through a 100- $\mu \mathrm{m}$ BD Falcon Cell Strainers (BD Bioscience, Oxford, UK) to remove debris. The resulting cell suspensions were pelleted by $5 \mathrm{~min}$ of centrifugation at 900 r.p.m. and resuspended and plated in alpha-modified Eagle's medium (Sigma-Aldrich), containing 1\% (v/v) P-S and 10\% (v/v) FBS (stem cell growth media, SCGM). Cultures were maintained on $75 \mathrm{~cm}^{2}$ flasks incubated at $37^{\circ} \mathrm{C}$ and $5 \% \mathrm{CO}_{2}$. When flasks were confluent, cells were detached with trypsinEDTA (Invitrogen, Life Technologies), split and re-plated.

Glial differentiation of stem cells. dASCs were obtained as previously described. ${ }^{14}$ Briefly, passage 1-3 ASC cultures were incubated for $24 \mathrm{~h}$ in SCGM containing $1 \mathrm{mM} \beta$-mercaptoethanol (Sigma-Aldrich), and this was followed by 3 days of further cell-preconditioning in SCGM supplemented with $35 \mathrm{ng} / \mathrm{ml}$ all-trans-retinoic acid (Sigma-Aldrich). The medium was then replaced with stem cell differentiation medium containing $5 \mathrm{ng} / \mathrm{ml}$ platelet-derived growth factor (Sera Laboratories International, Haywards Heath, UK), $10 \mathrm{ng} / \mathrm{ml}$ basic fibroblast growth factor (Sera Laboratories International), $14 \mu \mathrm{M}$ fsk and $126 \mathrm{ng} / \mathrm{ml}$ GGF-2 (Acorda Therapeutics Inc.). The cells were incubated for 2 weeks under these conditions, passaged with trypsin-EDTA when needed, and fresh medium was added approximately every $72 \mathrm{~h}$. Successful differentiation into a glial phenotype was confirmed by immunocytochemical assessment of glial markers, as previously reported. ${ }^{35,36}$

Reverse transcriptase-PCR. Cells were collected from sub-confluent flasks of each experimental group (aSC, nSC and ASC before and after glial differentiation). Total RNA was extracted using RNeasyTM Mini Kit (Qiagen, Manchester, UK), according to the manufacturer protocol. Extracted RNA was treated with DNAse (Qiagen) to eliminate genomic contamination and finally eluted in water. After the measure of the concentrations by ultraviolet spectrophotometry, $1-10 \mathrm{ng}$ of each RNA sample were reverse-transcripted for $30 \mathrm{~min}$ at $50^{\circ} \mathrm{C}$ and cDNAs were amplified using One-Step RT-PCR kit (Qiagen) with the following PCR cycling protocol (35 cycles): $30 \mathrm{~s}$ of denaturation at $95^{\circ} \mathrm{C}$ for $30 \mathrm{~s}$, annealing for $1 \mathrm{~min}$ (optimal temperatures are indicated Table 1 for each primer pair), primer extension at $72{ }^{\circ} \mathrm{C}$ for $90 \mathrm{~s}$ and a final extension step of $10 \mathrm{~min}$ at $72{ }^{\circ} \mathrm{C}$. The primer sequences and product size for all RT-PCRs are described in Table 1. For $\mathrm{P} 2 \mathrm{X}_{1-2}$ and $\mathrm{P} 2 \mathrm{X}_{5-6}, 10 \mathrm{ng}$ of RNA was used as starting template. Specific primers for the housekeeping gene, $\beta$-actin were used to confirm reverse transcription and ensure equal loading (see Table 1). A reaction omitting the template was carried out as a negative control.

Western blot analysis. Whole-cell lysates were obtained by scraping cells from confluent flasks using a lysis buffer containing $20 \mathrm{mM}$ 4-(2-hydroxyethyl)1-piperazineethanesulfonic acid (HEPES, pH 7.4) buffer, $100 \mathrm{mM} \mathrm{NaCl}, 1 \%$ (v/v) Nonidet P-40, $5 \mathrm{mM}$ EDTA and a cocktail of protease and phosphatase inhibitors (Thermo Scientific, Loughborough, UK). Lysates were incubated for $30 \mathrm{~min}$ on ice and, after freeze-thaw, protein concentrations were determined using the Bio-Rad detergent-compatible protein assay (Bio-Rad Laboratories, Hemel Hempstead, UK). Before loading, proteins were denaturated for $5 \mathrm{~min}$ at $95^{\circ} \mathrm{C}$ in reducing NUPAGE LDS sample buffer, and $30 \mu \mathrm{g}$ of proteins were separated at $160 \mathrm{~V}$ for $1 \mathrm{~h}$ on Bis-Tris gels NuPage Novex gels (Life Technologies, UK). Following electrophoretic separation, the proteins were transferred to nitrocellulose membranes (GE Healthcare, Little Chalfont, UK) for $1 \mathrm{~h}$ at $350 \mathrm{~mA}$. In order to confirm successful protein transfer, membranes were stained with Pounceau red (Sigma, UK), before being blocked for $30 \mathrm{~min}$ in a Tris-buffered saline (TBS)Tween solution (20 mM Tris pH 8, $250 \mathrm{mM} \mathrm{NaCl}, 0.1 \%$ (v/v) Tween) containing $5 \%$ (w/v) of non-fat dry milk. The membranes were thus incubated at $4^{\circ} \mathrm{C}$ in the following primary antibodies diluted in blocking buffer: rabbit polyclonal anti-P2X (1:500; Alomone Labs, Jerusalem, Israel) and rabbit polyclonal anti-P2X (1:500; Alomone Labs). After overnight incubation, membranes were washed with TBS-Tween and thus incubated for $1 \mathrm{~h}$ with an anti-rabbit horseradish peroxidaseconjugated (HRP) secondary antibody (1:2000; Cell Signaling, Hitchin, UK) for chemiluminescence detection. Finally, blots were stripped for $30 \mathrm{~min}$ at room temperature with a stripping buffer (Thermo Scientific) to remove the antibodies bound to the nitrocellulose. After further blocking in TBS milk, membranes were re-probed, using a rabbit primary antiserum directed against $\beta$-tubulin $(1: 2000$, Abcam, Cambridge, UK), followed by antigen detection with an anti-rabbit HRPconjugated secondary antibody (1:2000; Cell Signaling). Membranes were exposed to SuperSignal West Pico Chemiluminescent Substrate (Thermo Scientific) for signal detection, and images were acquired with a Kodak Image Station $4000 \mathrm{~mm}$ pro digital imaging system (Kodak, Rochester, NY, USA). 
Immunocytochemistry. Cells from each experimental group were plated on chamber slides (Nunc-Fisher Scientific, UK) or glass coverslips at a density of $5 \times 10^{3}$ cells per $\mathrm{cm}^{2}$ for all immunocytochemical studies. Twenty-four hours after seeding, cells were fixed for $15 \mathrm{~min}$ in $4 \%$ (w/v) paraformaldehyde (Sigma-Aldrich) and washed in phosphate-buffered solution (PBS). After $30 \mathrm{~min}$ of permeabilisation with $0.2 \%(\mathrm{v} / \mathrm{v})$ Triton X-100 at room temperature, slides and coverslips were blocked for $1 \mathrm{~h}$ with normal goat or donkey serum solution (both 1:100; Sigma). The following primary antibodies were applied overnight at $4{ }^{\circ} \mathrm{C}$ for $\mathrm{P} 2 \mathrm{X}_{4}$

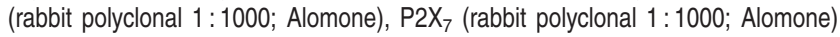
and GFAP (mouse monoclonal 1:500; Thermo Scientific). After $24 \mathrm{~h}$, slides were rinsed in PBS before incubation in Alexa Fluor 488 goat anti-rabbit IgG or Alexa Fluor 568 donkey anti-mouse IgG secondary antibodies (both from Life Technologies), depending on the host species of the primary antibodies. After final washing with PBS, slides were mounted using Vectashield mounting medium for fluorescence containing 4',6- diamidino-2-phenylindole for nuclear staining (Vector Laboratories, Peterborough, UK). Finally, images were acquired using a fluorescence microscope (Olympus BX60, Southend-on-Sea, UK) and processed with ImageJ 64 imaging software (National Institutes of Health NIH, Bethesda, MD, USA).

Calcium imaging techniques. For intracellular $\mathrm{Ca}^{2+}$ measurements cells were seeded at confluence on glass coverslips (for confocal imaging analysis) or on 96-well essay plates (Corning, CellBIND surface, Tewksbury, MA, USA, for multiplate reader measurements). After overnight incubation, cells were loaded for $40 \mathrm{~min}$ at $37^{\circ} \mathrm{C}$ with $3 \mu \mathrm{M}$ of Fluo-4-AM or $10 \mu \mathrm{M}$ Fura2-AM in Krebs-Ringer-modified buffer (KRB): $136 \mathrm{mM} \mathrm{NaCl}, 20 \mathrm{mM}$ HEPES, $5.5 \mathrm{mM}$ glucose, $1.2 \mathrm{mM} \mathrm{KH}_{2} \mathrm{PO}_{4}, 1.2 \mathrm{mM} \mathrm{MgSO}_{4}, 5 \mathrm{mM} \mathrm{NaHCO}_{3}, 1.8 \mathrm{mM}$ $\mathrm{KCl}, 2 \mathrm{mM} \mathrm{CaCl} 2 \mathrm{pH} 7.4$ (all from Sigma-Aldrich) supplemented with $0.01 \%$ pluronic acid (Molecular Probes, Life Technologies). For confocal imaging using Fluo-4, after de-esterification in KRB $\left(20 \mathrm{~min}\right.$ at $\left.37^{\circ} \mathrm{C}\right)$, the coverslips were placed in a perfusing chamber, mounted on the stage of an inverted confocal microscope (Nikon Eclipse TE300; Nikon UK Itd, Surrey, UK). Cells were superfused with $\mathrm{KRB}$ at $8 \mathrm{ml} / \mathrm{min}$, maintained at $37^{\circ} \mathrm{C}$ and excited at $488 \mathrm{~nm}$ by excitation laser (emitted light filtered at $515 \pm 30 \mathrm{~nm}$ ). Images were acquired using $\times 20$ dry objective (NA 0.5 ). Drugs were applied by superfusion. Similarly, for Flexstation multiplate reader measurements (Flexstation 3, Molecular Devices, Sunnyvale, CA, USA), the cells were loaded with Fura-2-AM and de-esterified for $20 \mathrm{~min}$ at $37^{\circ} \mathrm{C}$. Cultures were excited at 335 and $363 \mathrm{~nm}$, and emission was measured at $510 \mathrm{~nm}$. ATP treatments were performed after $20 \mathrm{~s}$ and fluorescence emission was monitored for $4 \mathrm{~min}$. Technically, it was not possible to test ATP concentrations $>1 \mathrm{mM}$ because, at higher concentrations, cells detached from the coverslips and from the tissue culture plates making fluorescence detection impossible with the Flexstation system. For the experiments investigating the contribution of $\mathrm{P} 2 \mathrm{Y}$ receptors to intracellular $\mathrm{Ca}^{2+}$ increase, $\mathrm{Ca}^{2+}$ was omitted from the KRB solution. In the Flexstation measurements, cells were preincubated for $10 \mathrm{~min}$ with a potent $\mathrm{P} 2 \mathrm{X}_{7}$ specific inhibitor (AZ 10606120 dihydrochloride, $300 \mathrm{nM}$, Tocris Bioscience, Bristol, UK) before treatment with ATP $1 \mathrm{mM}$ (Sigma-Aldrich). Data were expressed as a ratio between the fluorescence recorded after stimulation $(335 / 363 \mathrm{~nm}, n=4)$. For the quantification of the AUC in Flestation experiments, GraphPad Prism (GraphPad Software Inc., San Diego, CA, USA) was used setting the first three data point of each curve as baseline. Data were expressed as AUC arbitrary units \pm S.E.M.

Electrophysiology. dASC and uASCs $\left(3 \times 10^{3}\right)$ were seeded separately onto 12-mm-diameter glass coverslips. Recording pipettes were pulled from borosilicate glass (Harvard Apparatus, Kent, UK) and had resistances of 2-5 M $\Omega$ when filled with the intracellular pipette solution containing (in $\mathrm{mM}$ ) $147 \mathrm{NaCl}, 10$ HEPES and 10 EGTA. This solution contained (in mM) $147 \mathrm{NaCl}, 10$ HEPES, 13 glucose, $2 \mathrm{KCl}, 2 \mathrm{CaCl}_{2}$ and $1 \mathrm{MgCl}_{2}$. All solutions were maintained at $300-$ $320 \mathrm{mOsm} / \mathrm{l}$ and $\mathrm{pH} 7.3$ (adjusted with $\mathrm{NaOH}$ ). Whole-cell patch clamp recordings were made at room temperature using a HEKA EPC9 patch clamp amplifier and Pulse acquisition software (HEKA, Lambrecht, Germany). Recordings were made at a holding potential of $-60 \mathrm{mV}$. The data were low-pass filtered at $3 \mathrm{kHz}$ and sampled at $1 \mathrm{kHz}$. Solutions were directly applied to cells using an RSC-160 rapid perfusion system (Biologic Science Instruments, Claix, France-Isère, France), with tubes positioned $\sim 100 \mu \mathrm{m}$ away from the cell. Current amplitudes were expressed as current densities (pA/pF).
Cell death and survival assays. To investigate the effect of $P 2 X_{7}$ receptors stimulation on cell death and survival, $\mathrm{dASC}$ cultures were treated with ATP in the presence of the specific $P 2 X_{7}$ antagonist AZ 10606120 dihydrochloride $(300 \mathrm{nM})$.

Cytotoxicity was assessed via a Cytotoxicity Detection Kit (Roche Applied Science, Burgess Hill, UK), a colorimetric assay based on the measurement of LDH released from the cytosol of damaged cells in the cytoplasm. Briefly, cells were seeded on 96-well essay plates (Corning, CellBIND surface) at a density of $2 \times 10^{5}$ cells per well. After overnight incubation, cells were washed with KRB and preincubated for 10 min with AZ 10606120 dihydrochloride (300 nM) in KRB, and controls were treated with drug vehicle. After $10 \mathrm{~min}$ incubation at $37^{\circ} \mathrm{C}$ and $5 \%$ $\mathrm{CO}_{2}$, cells were treated for $1 \mathrm{~h}$ with $5 \mathrm{mM}$ ATP to induce cell death. In the experiments for the determination of the optimal ATP concentration, cells were incubated in KRB only before ATP $(1-10 \mathrm{mM})$ treatments. NT controls were used to assess spontaneous LDH release and NT cells lysed with Triton X-100 were used to determine the total amount of LDH in the cytoplasm. After $1 \mathrm{~h}$ incubation, supernatant were collected and spun at 1500 r.p.m. for 5 min at $4{ }^{\circ} \mathrm{C}$ to remove cell debris. The cytotoxicity assay was performed according to manufacturer's protocol and LDH levels were measured by absorbance reading at $492 \mathrm{~nm}$ using a Asys UVM-340 microplate reader/spectrophotometer (Biochrom Ltd., Cambridge, UK). Data were expressed as percentage versus Triton X-100 cell lysates \pm S.E.M. $(n=6)$.

To further prove ATP-induced cell death, a different cell viability assay based on the membrane-impermeant viability indicator EthD-1 (Molecular Probes) was performed. This high-affinity nucleic-acid stain binds DNA of dead cells and emits red fluorescence. Cells were seeded and treated as in LDH assay, and were incubated overnight at $37^{\circ} \mathrm{C}$ and $5 \% \mathrm{CO}_{2}$. At the end of the pharmacological treatments, cells were incubated for 20 min at $37^{\circ} \mathrm{C}$ in $4 \mu \mathrm{M}$ EthD-1 in KRB. At the end of the incubation, cells were examined under a fluorescent inverted microscope (Olympus IX51). For each well, an image covering an $\sim 50 \%$ of the surface area was acquired and the stained cells were counted using the counting tool of Image Pro Plus image analysis software (Media Cybernetics, Rockville, MD, USA). Data were expressed as dead cells per field \pm S.E.M. $(n=6)$.

Cell survival was assessed via the CellTiter 96 AQueous One Solution Cell Proliferation Assay (Promega, Southampton, UK), a colorimetric method for determining the number of viable cells based on a novel tetrazolium compound, inner salt (MTS). MTS is bioreduced by viable cells into a coloured formazan compound. Cells were seeded and treated as for the cytotoxicity assay; nevertheless, following ATP treatment cells were incubated with the MTS solution according to manufacturer's protocol for $3 \mathrm{~h}$, and absorbance at $490 \mathrm{~nm}$ was measured using a Asys UVM-340 microplate reader/spectrophotometer (Biochrom Ltd.). Data were expressed as percentage versus the NT controls \pm S.E.M. $(n=6)$.

Statistical analyses. Statistical significance for electrophysiology, cell death and survival assays was estimated by one-way analysis of variance with Tukey's multiple comparison tests, using GraphPad Prism 6 (GraphPad Software Inc.). For Flexstation studies, unpaired $t$-test was performed. Levels of significance were expressed as $P$-values ( ${ }^{\star} P<0.05,{ }^{* \star} P<0.01,{ }^{* \star} P<0.001$ and $\left.{ }^{* \star * \star} P<0.0001\right)$.

\section{Conflict of Interest}

The authors declare no conflict of interest.

Acknowledgements. This study was supported by Wellcome Trust. We thank Acorda Therapeutics, USA, for kindly supplying GGF-2 used in this study. We are also grateful to the Hargreaves and Ball Trust, and to the Wellcome Trust Institutional Strategic Support Fund for their generous financial support.

1. Terenghi G, Wiberg M, Kingham PJ. Chapter 21: use of stem cells for improving nerve regeneration. Int Rev Neurobiol 2009; 87: 393-403.

2. Adams AM, Arruda EM, Larkin LM. Use of adipose-derived stem cells to fabricate scaffoldless tissue-engineered neural conduits in vitro. Neuroscience 2012; 201: 349-356.

3. Zochodne DW. The challenges and beauty of peripheral nerve regrowth. J Peripher Nerv Syst 2012; 17: 1-18.

4. Wiberg M, Terenghi G. Will it be possible to produce peripheral nerves? Surg Technol Int 2003; 11: 303-310.

5. Chalfoun CT, Wirth GA, Evans GR. Tissue engineered nerve constructs: where do we stand? J Cell Mol Med 2006; 10: 309-317.

6. Mirsky R, Jessen KR. The neurobiology of Schwann cells. Brain Pathol 1999; 9: 293-311. 
7. Chen ZL, Yu WM, Strickland S. Peripheral regeneration. Annu Rev Neurosci 2007; 30 209-233.

8. Ide C. Peripheral nerve regeneration. Neurosci Res 1996; 25: 101-121.

9. Guenard V, Kleitman N, Morrissey TK, Bunge RP, Aebischer P. Syngeneic Schwann cells derived from adult nerves seeded in semipermeable guidance channels enhance peripheral nerve regeneration. J Neurosci 1992; 12: 3310-3320.

10. Mosahebi A, Fuller P, Wiberg M, Terenghi G. Effect of allogeneic Schwann cell transplantation on peripheral nerve regeneration. Exp Neurol 2002; 173: 213-223.

11. Mosahebi A, Woodward B, Wiberg M, Martin R, Terenghi G. Retroviral labeling of Schwann cells: in vitro characterization and in vivo transplantation to improve peripheral nerve regeneration. Glia 2001; 34: 8-17.

12. Tohill M, Terenghi G. Stem-cell plasticity and therapy for injuries of the peripheral nervous system. Biotechnol Appl Biochem 2004; 40(Pt 1): 17-24

13. Jiang L, Zhu JK, Liu XL, Xiang P, Hu J, Yu WH. Differentiation of rat adipose tissue-derived stem cells into Schwann-like cells in vitro. Neuroreport 2008; 19: 1015-1019.

14. Kingham PJ, Kalbermatten DF, Mahay D, Armstrong SJ, Wiberg M, Terenghi G. Adipose-derived stem cells differentiate into a Schwann cell phenotype and promote neurite outgrowth in vitro. Exp Neurol 2007; 207: 267-274

15. Xu Y, Liu L, Li Y, Zhou C, Xiong F, Liu Z et al. Myelin-forming ability of Schwann cell-like cells induced from rat adipose-derived stem cells in vitro. Brain Res 2008; 1239: 49-55.

16. Radtke C, Schmitz B, Spies M, Kocsis JD, Vogt PM. Peripheral glial cell differentiation from neurospheres derived from adipose mesenchymal stem cells. Int J Dev Neurosci 2009; 27 817-823.

17. Razavi S, Ahmadi N, Kazemi M, Mardani M, Esfandiari E. Efficient transdifferentiation of human adipose-derived stem cells into Schwann-like cells: a promise for treatment of demyelinating diseases. Adv Biomed Res 2012; 1: 12.

18. Tomita K, Madura T, Sakai Y, Yano K, Terenghi G, Hosokawa K. Glial differentiation of human adipose-derived stem cells: implications for cell-based transplantation therapy. Neuroscience 2013; 236: 55-65.

19. Mantovani C, Mahay D, Kingham M, Terenghi G, Shawcross SG, Wiberg M. Bone marrow- and adipose-derived stem cells show expression of myelin mRNAs and proteins. Regen Med 2010; 5: 403-410.

20. Tomita K, Madura T, Mantovani C, Terenghi G. Differentiated adipose-derived stem cells promote myelination and enhance functional recovery in a rat model of chronic denervation. J Neurosci Res 2012; 90: 1392-1402.

21. Kaewkhaw R, Scutt AM, Haycock JW. Anatomical site influences the differentiation of adiposederived stem cells for Schwann-cell phenotype and function. Glia 2011; 59: 734-749.

22. di Summa PG, Kalbermatten DF, Pralong E, Raffoul W, Kingham PJ, Terenghi G. Long-term in vivo regeneration of peripheral nerves through bioengineered nerve grafts. Neuroscience 2011; 181: 278-291.

23. di Summa PG, Kingham PJ, Raffoul W, Wiberg M, Terenghi G, Kalbermatten DF Adipose-derived stem cells enhance peripheral nerve regeneration. J Plast Reconst Aesthet Surg 2010; 63: 1544-1552.

24. Sun F, Zhou K, Mi WJ, Qiu JH. Combined use of decellularized allogeneic artery conduits with autologous transdifferentiated adipose-derived stem cells for facial nerve regeneration in rats. Biomaterials 2011; 32: 8118-8128.

25. Zhang $Y$, Luo $H$, Zhang Z, Lu Y, Huang X, Yang L et al. A nerve graft constructed with xenogeneic acellular nerve matrix and autologous adipose-derived mesenchymal stem cells. Biomaterials 2010; 31: 5312-5324

26. Erba P, Mantovani C, Kalbermatten DF, Pierer G, Terenghi G, Kingham PJ. Regeneration potential and survival of transplanted undifferentiated adipose tissue-derived stem cells in peripheral nerve conduits. J Plast Reconstr Aesthet Surg 2010; 63: e811-e817.

27. Walsh S, Midha R. Practical considerations concerning the use of stem cells for peripheral nerve repair. Neurosurg Focus 2009; 26: E2.

28. Walsh SK, Kumar R, Grochmal JK, Kemp SW, Forden J, Midha R. Fate of stem cell transplants in peripheral nerves. Stem Cell Res 2012; 8: 226-238.

29. Magnaghi V, Procacci P, Tata AM. Chapter 15: Novel pharmacological approaches to Schwann cells as neuroprotective agents for peripheral nerve regeneration. Int Rev Neurobiol 2009; 87: 295-315

30. Verderio C, Bianco F, Blanchard MP, Bergami M, Canossa M, Scarfone E et al. Cross talk between vestibular neurons and Schwann cells mediates BDNF release and neuronal regeneration. Brain Cell Biol 2006; 35: 187-201.

31. Magnaghi V, Ballabio M, Consoli A, Lambert JJ, Roglio I, Melcangi RC. GABA receptor-mediated effects in the peripheral nervous system: a cross-interaction with neuroactive steroids. J Mol Neurosci 2006; 28: 89-102.

32. Magnaghi V, Ballabio M, Cavarretta IT, Froestl W, Lambert JJ, Zucchi I et al. GABAB receptors in Schwann cells influence proliferation and myelin protein expression. Eur J Neurosci 2004; 19: 2641-2649.

33. Fields RD, Stevens B. ATP: an extracellular signaling molecule between neurons and glia. Trends Neurosci 2000; 23: 625-633.

34. Procacci P, Ballabio M, Castelnovo LF, Mantovani C, Magnaghi V. GABA-B receptors in the PNS have a role in Schwann cells differentiation? Front Cell Neurosci 2012; 6: 68

35. Faroni A, Terenghi G, Magnaghi V. Expression of functional gamma-aminobutyric acid type a receptors in Schwann-like adult stem cells. J Mol Neurosci 2012; 47: 619-630.
36. Faroni A, Mantovani C, Shawcross SG, Motta M, Terenghi G, Magnaghi V. Schwann-like adult stem cells derived from bone marrow and adipose tissue express gamma-aminobutyric acid type B receptors. J Neurosci Res 2011; 89: 1351-1362.

37. Faroni A, Calabrese F, Riva MA, Terenghi G, Magnaghi V. Baclofen modulates the expression and release of neurotrophins in schwann-like adipose stem cells. $J \mathrm{Mo}$ Neurosci 2013; 49: 233-243.

38. Zippel N, Limbach CA, Ratajski N, Urban C, Luparello C, Pansky A et al. Purinergic receptors influence the differentiation of human mesenchymal stem cells. Stem Cells Dev 2012; 21: 884-900.

39. Fields RD, Burnstock G. Purinergic signalling in neuron-glia interactions. Nat Rev Neurosci 2006; 7: 423-436.

40. Verkhratsky A, Krishtal OA, Burnstock G. Purinoceptors on neuroglia. Mol Neurobiol 2009; 39: 190-208.

41. Burnstock $\mathrm{G}$. Purinergic signalling: its unpopular beginning, its acceptance and its exciting future. Bioessays 2012; 34: 218-225.

42. Burnstock G, Verkhratsky A. Long-term (trophic) purinergic signalling: purinoceptors control cell proliferation, differentiation and death. Cell Death Dis 2010; 1: e9.

43. Wang X, Arcuino G, Takano T, Lin J, Peng WG, Wan P et al. P2X7 receptor inhibition improves recovery after spinal cord injury. Nat Med 2004; 10: 821-827.

44. Di Virgilio F. Liaisons dangereuses: $\mathrm{P} 2 \mathrm{X}(7)$ and the inflammasome. Trends Pharmacol Sci 2007; 28: 465-472.

45. Di Virgilio F, Chiozzi P, Falzoni S, Ferrari D, Sanz JM, Venketaraman V et al. Cytolytic P2X purinoceptors. Cell Death Differ 1998; 5: 191-199.

46. Mantovani C, Raimondo S, Haneef MS, Geuna S, Terenghi G, Shawcross SG et al. Morphological, molecular and functional differences of adult bone marrow- and adiposederived stem cells isolated from rats of different ages. Exp Cell Res 2012; 318: 2034-2048.

47. Stevens B, Fields RD. Response of Schwann cells to action potentials in development. Science 2000; 287: 2267-2271.

48. Matute C, Torre I, Perez-Cerda F, Perez-Samartin A, Alberdi E, Etxebarria E et al. P2X(7) receptor blockade prevents ATP excitotoxicity in oligodendrocytes and ameliorates experimental autoimmune encephalomyelitis. J Neurosci 2007; 27: 9525-9533.

49. Khakh BS, North RA. P2X receptors as cell-surface ATP sensors in health and disease. Nature 2006; 442: 527-532.

50. Lecca D, Ceruti S, Fumagalli M, Abbracchio MP. Purinergic trophic signalling in glial cells: functional effects and modulation of cell proliferation, differentiation, and death. Purinergic Signal 2012; 8: 539-557.

51. Shimizu S, Kitada M, Ishikawa H, Itokazu Y, Wakao S, Dezawa M. Peripheral nerve regeneration by the in vitro differentiated-human bone marrow stromal cells with Schwann cell property. Biochem Biophys Res Commun 2007; 359: 915-920.

52. McKenzie IA, Biernaskie J, Toma JG, Midha R, Miller FD. Skin-derived precursors generate myelinating Schwann cells for the injured and dysmyelinated nervous system. $J$ Neurosci 2006; 26: 6651-6660.

53. Hill CE, Hurtado A, Blits B, Bahr BA, Wood PM, Bartlett Bunge $M$ et al. Early necrosis and apoptosis of Schwann cells transplanted into the injured rat spinal cord. Eur J Neurosci 2007: 26: 1433-1445.

54. Pearse DD, Sanchez AR, Pereira FC, Andrade CM, Puzis R, Pressman Y et al. Transplantation of Schwann cells and/or olfactory ensheathing glia into the contused spinal cord: Survival, migration, axon association, and functional recovery. Glia 2007; 55: 976-1000.

55. Tse KH, Kingham PJ, Novikov LN, Wiberg M. Adipose tissue and bone marrow-derived stem cells react similarly in an ischaemia-like microenvironment. J Tissue Eng Regen Med 2012; 6: 473-485.

56. Zhu W, Chen J, Cong X, Hu S, Chen X. Hypoxia and serum deprivation-induced apoptosis in mesenchymal stem cells. Stem Cells 2006; 24: 416-425.

57. Grafe P, Schaffer V, Rucker F. Kinetics of ATP release following compression injury of a peripheral nerve trunk. Purinergic Signal 2006; 2: 527-536.

58. Shin YH, Lee SJ, Jung J. Secretion of ATP from Schwann cells through lysosomal exocytosis during Wallerian degeneration. Biochem Biophys Res Commun 2012; 429 : 163-167.

59. Shin YH, Lee SJ, Jung J. Extracellular ATP inhibits Schwann cell dedifferentiation and proliferation in an ex vivo model of Wallerian degeneration. Biochem Biophys Res Commun 2013; 430: 852-857.

60. Sulaiman $\mathrm{OA}$, Gordon T. Role of chronic Schwann cell denervation in poor functional recovery after nerve injuries and experimental strategies to combat it. Neurosurgery 2009; 65(4 Suppl): A105-A114.

61. Shibuya I, Tanaka K, Hattori Y, Uezono Y, Harayama N, Noguchi J et al. Evidence that multiple $\mathrm{P} 2 \mathrm{X}$ purinoceptors are functionally expressed in rat supraoptic neurones. J Physiol 1999; 514(Pt 2): 351-367.

Cell Death and Disease is an open-access journal (c)
licensed under a Creative Commons Attribution-NonCommercialNoDerivs 3.0 Unported License. To view a copy of this license, visit http://creativecommons.org/licenses/by-nc-nd/3.0/ 